\title{
Night Soil: Origins, Discontinuities, and Opportunities for Bridging the Metabolic Rift
}

\author{
Nicholas C. Kawa ${ }^{1 *}$, Yang Ding ${ }^{2}$, Jo Kingsbury ${ }^{2}$, Kori Goldberg $^{3}$, Forbes Lipschitz ${ }^{4}$, Mitchell Scherer ${ }^{4}$, and Fatuma Bonkiye ${ }^{1}$ \\ ${ }^{1}$ Department of Anthropology, The Ohio State University, Columbus, USA. ${ }^{2}$ School of Environment and Natural Resources, \\ The Ohio State University, Columbus, USA. ${ }^{3}$ World Wildlife Fund, District of Columbia, USA. ${ }^{4}$ Knowlton School of \\ Architecture, The Ohio State University, Columbus, USA. \\ *kawa.5@osu.edu
}

\begin{abstract}
For millennia, people have relied on human excrement or "night soil" as a source of agricultural fertilization. Following industrialization, however, the use of this resource became considerably limited. In this article, we provide a brief overview of the historical use of human excreta for agricultural application at varying scales of management, from early Amazonian farming middens to regional networks of night soil trade in imperial China. We then draw attention to the factors that led to the discontinuation of night soil usage during industrialization, placing focus on the "culture of flushing" that developed along with the adoption of the hydraulic sanitation system. To conclude, we consider how improved management of human excreta in the contemporary world can have important consequences for agricultural production, despite the ongoing challenges posed by what Marxian scholars refer to as the metabolic rift-the disruption of the earth's socio-ecological cycles brought on by industrial capitalism.
\end{abstract}

Received June 26, 2018

OPENӘACCESS

Accepted May 16, 2019

DOI 10.14237/ebl.10.1.2019.1351

Published July 18, 2019

Keywords Biosolids, Excrement, Humanure, Soil management practice, Agroecology

Copyright (c) 2019 by the author(s) licensee Society of Ethnobiology. This is an open-access article distributed under the terms of the Creative Commons Attribution-NonCommercial 4.0 International Public License (https://creativecommons.org/licenses/by-nc/4.0), which permits non-commercial use, distribution, and reproduction in any medium, provided the original author and source are credited.

\section{Introduction}

For millennia, farmers across the world have relied on human excrement as a fertilizer, often known euphemistically as "night soil" (Kawa 2016a; King 1911; Van Der Geest 2002; Xue 2005). In the 19th century, however, a host of factors related to urban and industrial growth in Europe and North America led to the adoption of water-borne waste removal, which became the basis of the modern hydraulic sanitation system. With this development emerged a "culture of flushing"-intertwining attitudes, infrastructure, and legal codes that resulted in the channeling of human excrement into subterranean networks and waterways (Benidickson 2007). In effect, this disrupted the cycling of nutrients from urban metropolises to surrounding agricultural lands, provoking what Marxian scholars now describe as the metabolic rift (Foster 1999; see also Moore 2011).

Environmental sociologist John Bellamy Foster introduced the concept of the metabolic rift through a close reading of Marx, who had observed a break in "the metabolic interaction between man and earth" driven by the removal of soil nutrients under capitalist agriculture and a neglect for their systematic restoration (Foster 1999:380). In Capital Volume 1, Marx (1979:506) declared: "All progress in capitalist agriculture is a progress in the art, not only of robbing the worker, but of robbing the soil." Later, in Capital Volume 3 (1999:69), Marx specifically lamented how human excrement, which was once a resource for agricultural fertilization in Europe, had become a source of pollution and waste: "Excretions of consumption are of the greatest importance for agriculture. So far as their utilisation is concerned, there is an enormous waste of them in the capitalist economy. In London, for instance, they can find no better use for the excretion of four and a half million human beings than pollute the Thames with it, at heavy expense." Which is to say, Marx pinpointed the metabolic rift in the modern treatment of human excrement. 
Today, many initiatives around the world are attempting to address the metabolic rift by building more sustainable agricultural systems that restore localized nutrient cycles. Part of this effort is through the local food movement, which aims to devise locally-based and self-reliant food economies that enable sustainable food production, processing, distribution, and consumption (Feenstra 2002). An often less visible but no less significant movement is the growing interest in harnessing human excreta and returning it to the land as a soil amendment. In nations that maintain hydraulic sanitation systems, this is primarily done through the production of "biosolids"- treated sanitation sludge that can be spread over the surface of farm fields, or, when in liquid form, injected underground. Still, the use of this resource is considerably limited in most parts of the world today. In the United States, for example, the Environmental Protection Agency (EPA) estimates that approximately eight million dry tons of biosolids are produced in the country annually, but only about half of this material is land applied and USDAcertified organic agricultural operations are prohibited from using it. Though many farmers, researchers, and sanitation engineers view the use of biosolids as a beneficial model for agricultural fertilization on a planet of finite resources (Basta 1995; Cofie et al. 2005; Cordell et al. 2011), others have raised concerns about the potential consequences of biosolids usage for environmental and public health (Langdon et al. 2010; LeBlanc et al. 2006; Snyder 2005).

Our objective in this article is to contextualize contemporary debates concerning the use of human excreta in agricultural systems. To begin, we offer a condensed historical overview of night soil's use at varying scales of management. We then draw attention to the factors that led to the discontinuation of night soil's usage during industrialization, placing focus on the "culture of flushing" that developed alongside the hydraulic sanitation system. To conclude, we consider both the benefits and potential problems that human excreta poses for agricultural fertilization. In doing so, we hope to bring some clarity to the challenges of "closing the loop" in contemporary sanitation systems as well as the ways we might begin to address the Marxian metabolic rift.

\section{A (Very) Brief History of Night Soil Management} In many regions of the world, human excrement or "night soil" was used historically to improve or maintain soil fertility, particularly in response to agricultural intensification. But this was not always an intentional management practice among early farmers, as can be seen in the case of Amazonian Dark Earth (ADE). Distributed in patches across the Amazon basin, ADE is an anthropogenic soil known for its significant concentrations of organic residues that contribute to its elevated fertility (Kawa 2016b:50-51). Conservative estimates place the emergence of ADE between 2000 and 2500 years ago, when it appears to have co-evolved with the rise of manioc agriculture in the region (Arroyo-Kalin 2010; cf. Moraes 2015; Neves et al. 2003). Hundreds of ADE sites have been identified to date, primarily along the banks of the Amazon and its major tributaries, where indigenous villagers deposited food refuse, vegetative charcoal, and various forms of manure, including human excrement (Birk et al. 2010; Glaser and Birk 2012). Recent soil scientific research has concluded that ADE was not intentionally created, but rather grew out of everyday midden activities, which produced a positive feedback loop that allowed for the growth of human populations in the region, and in turn, expansion of such anthropogenic soils (Glaser and Birk 2012). Whether Amazonian farming communities suffered from chronic disease as a result of these deposition practices remains unclear.

But in contrast to such seemingly inadvertent use, night soil was also systematically managed in large, complex societies. In Mesoamerica, for example, human excreta featured in one of the most striking agricultural innovations of the Aztec Empire-the chinampas. These "floating gardens" or artificial islands, connected through networks of canals, were created with aquatic plants and the sediments of lake beds. They ranged in dimensions from 2.5 to 10 meters wide and as many as 100 meters long. Dating back at least to $1100 \mathrm{AD}$, these raised islands were also fertilized with human excreta collected in the great city of Tenochtitlán. Prior to Spanish arrival, upwards of 1,000 men were regularly employed to manage the city's refuse and maintain its canal system. The chinampas, in turn, produced maize, beans, chili peppers, and tomatoes as well as a host of medicinal plants and agroforestry products that sustained the region's estimated 250,000 inhabitants. Today, it has been considered an early model of environmental and socio-economic sustainable management in a complex society (Merlín-Uribe et al. 2013).

In other large-scale civilizations, night soil even became a commodity integrated into networks of 


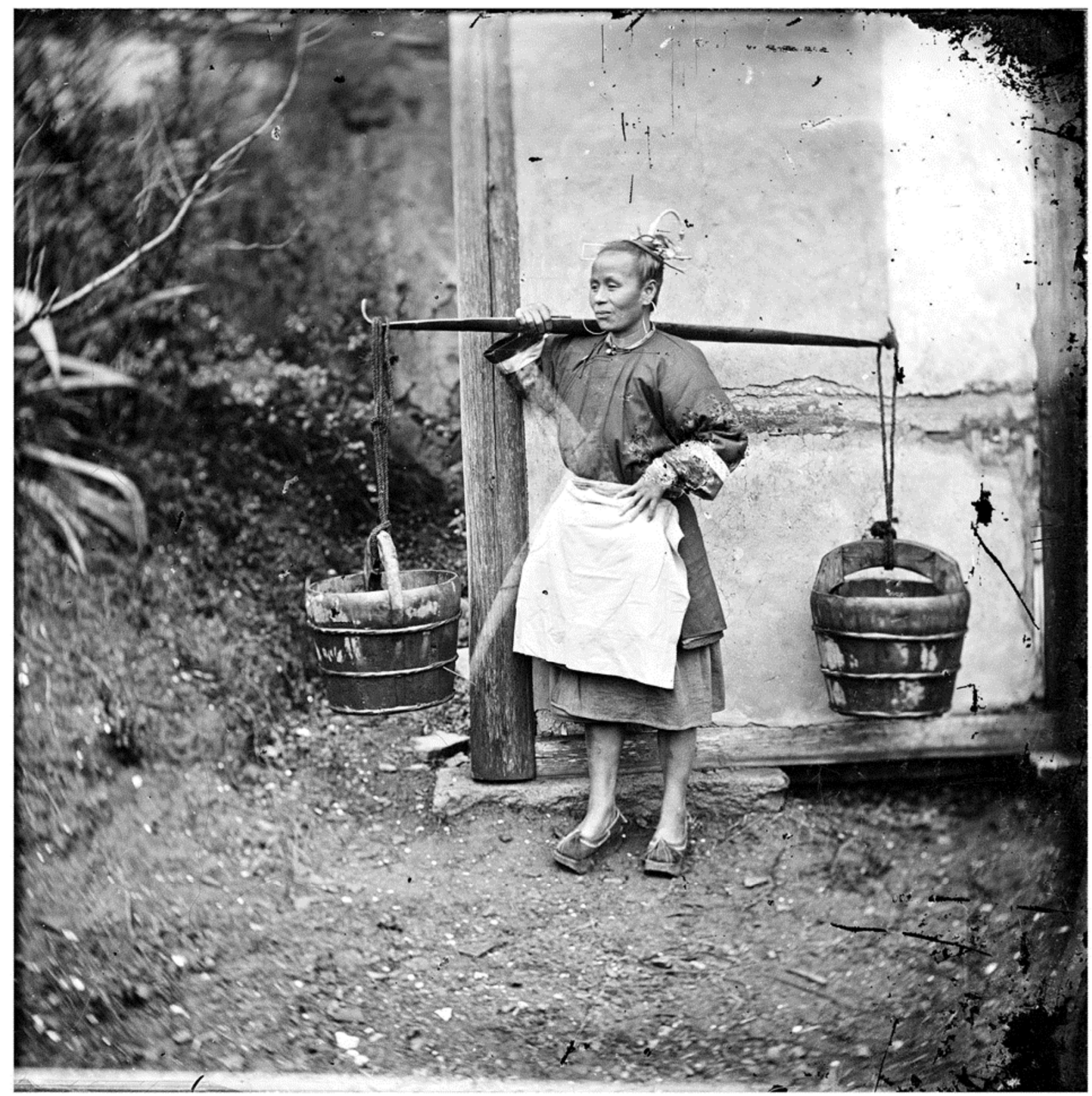

Figure 1 A woman carries buckets of night soil in Fuzhou, Fujian province, China. Photograph by John Thomson, 1871. CC BY 4.0. (Source: Wellcome Library no. 19724i).

regional trade (Figure 1). This is best documented in East Asia where night soil has an extensive history of agricultural use, dating back at least to the third century B.C. (McNeill and Winiwarter 2004). The earliest text describing the application of night soil as a fertilizer can be found in $Q^{i}$ Min Yao Shu, the first
Chinese agricultural instruction book, written between 553 and 554 AD (Jia and Huang 1977). Later, during the Qing dynasty (1736-95 AD), night soil grew into such a prized agricultural resource that its collection was referred to as "the business of the golden juice." Farmers not only sought out night soil for fertilization 
of their fields, but many also became involved in its sale and trade, traveling long distances to procure high-quality night soil from wealthy, urban areas (Xue 2005). Night soil depots or trading houses (fenchang) were established to handle the collection, transport, treatment, and sale of night soil, with many farmers eventually abandoning agricultural work in the late 19th and early 20th century to become night soil traders instead. Until the 1970s, urban toilet cleaners still paid for the night soil they collected from residents' houses in southern provinces (Xue 2005).

Like China, early modern Japan placed great economic value on night soil. In 1649, authorities in Edo (what is now Tokyo) banned toilets that discharged into canals or rivers to prevent human excrement from being wasted (Smil 2004:27). Across the country, night soil was also collected by professionals and sold to farmers-once traded for vegetables but later purchased with silver (Hanley 1987). By the mid-18th century, night soil had become so expensive that incidents of its theft began to appear in the record books (Hanley 1987). Near the height of its use, statistics from the Japanese Bureau of Agriculture showed that almost 24 million tons of excreta were used on approximately 13.5 million hectares of arable land in the year 1908 alone (King 1911). By the mid-20th century, however, the rise in the adoption of chemical fertilizer along with growing concerns regarding night soil's role in the spread of diseases (see Kim et al. 2014) led to a drastic reduction in its use in Asia (Ferguson 2014). Despite Europeans' and North Americans' admiration of Asian agricultural resource conservation (e.g., Ferguson 2014; King 1911), the large-scale abandonment of night soil in China and Japan mirrored a similar trend witnessed in Europe during industrialization.

\section{The Discontinuation of Night Soil Use during Industrialization}

Before the development of the modern hydraulic sanitation system, most European cities like London relied on night soil collectors to remove excrement from cesspits and privies. As in Asia, night soil was collected and then spread on agricultural fields in the rural countryside. However, the growing popularity of the flush toilet in the mid-19th century led to increased volumes of water in urban cesspits, which considerably diluted night soil and compromised its value for fertilization (Gandy 2004:366). To complicate matters, the expansion of cities pushed night soil collectors greater distances to reach their markets in rural areas. Not to mention, the cost of emptying a cesspit was double the daily wage of an average skilled laborer, which presented an additional obstacle to timely removal (Johnson 2006:10). Together, these factors created the conditions for a public health crisis-between 1831 and 1866, Britain was ravaged by four distinct cholera epidemics due to the contamination of drinking wells.

At the time, there was much debate in Europe over the flushing of human feces into newly constructed sewer systems that were originally designed to handle urban stormwater. Despite such debate, the idea of directing human excreta into city sewers became the most practical option, especially since running water was not believed to be at serious risk of contamination (Benidickson 2007:4). The model of the private flush toilet encouraged this "culture of flushing," channeling urban wastes into underground tunnels (Figure 2) and off into rivers and the open ocean.

Europe's adoption of the hydraulic sanitation system aligned with emerging conceptions of hygiene and cleanliness that had already begun to reshape urban social life and governance. In his analysis of the "civilizing process," Norbert Elias (2000) detailed how the concealment and restraint of bodily odors and excreta-along with bodily functions responsible for them-became important marks of social distinction in Europe between the $13^{\text {th }}$ and $18^{\text {th }}$ centuries. Moreover, Dominique LaPorte (2002) showed how the rise in power of the modern European state was derived from its ability to cleanse urban space and relegate the "dirty business" of human biological necessity to the private realm. Building on their observations, the cultural theorist Gay Hawkins (2003:40) has argued that the modern sanitation system functions as a "public secret" that ultimately prevents people from knowing "where shit ends up". Of course, this is no oversight but rather a feature of its design. In the United States, for example, some 600,000 miles of buried sewers whisk disposed solids and liquids away to municipal water treatment plants, often located on the urban fringe. It is only when such systems fail, as in the case of combined sewer overflows-where flushed excreta mixes with storm water runoff and discharges into urban waterways - that urban residents are confronted with the messy realities of modern hydraulic sanitation. 


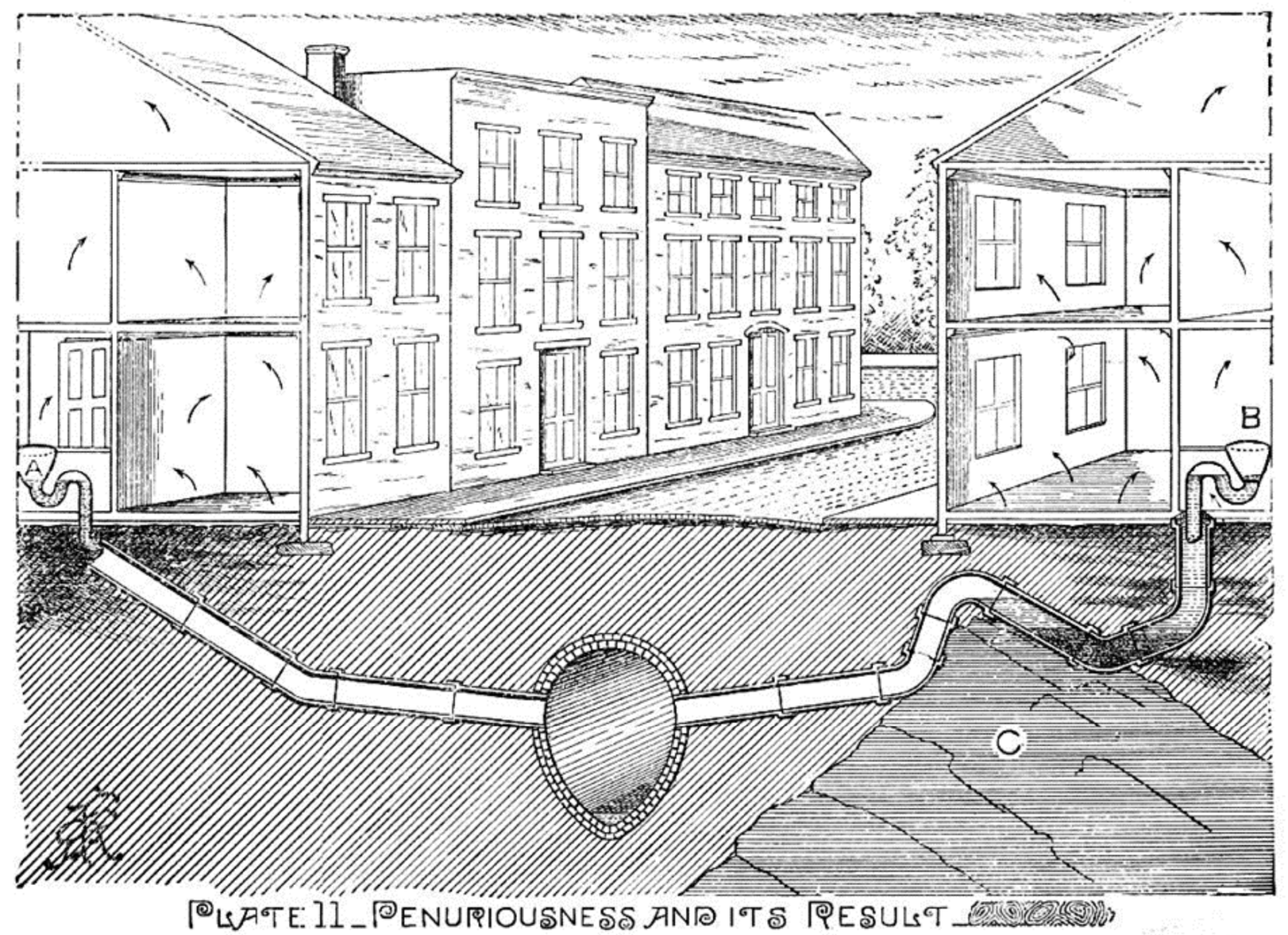

Figure 2 An early depiction of groundwater contamination and sewer gas leaks resulting from improper sewer construction. (Source: Sewers: Ancient and Modern by C. Wheeler, 1887).

But in many parts of the world, sanitation is a source of ongoing debate and contestation. Scholars working in developing countries like Ghana and South Africa have recently highlighted how sanitation has served as the basis for political mobilization of marginalized groups (Chalfin 2014; Robins 2010). At the same time, in the developed world, permaculturalists and other small-scale communities of agro-ecologists are pushing back against the culture of flushing by decoupling from the hydraulic sanitation system and taking matters into their own hands (Jenkins 1994; Pickering 1999). These different movements highlight the deep inequities in the global political economic system that manifest in the management of human excreta: while some communities suffer from a lack of improved sanitation and are simultaneously in need of resources for energy and fertilization, others are questioning the wastefulness of modern sanitation systems that require people to habitually defecate into clean water and send valuable nutrients into landfills. To add to the irony, many countries with hydraulic sanitation systems are simultaneously grappling with problems related to overuse of chemical fertilizer on agricultural lands, including massive algal blooms and the eutrophication of waterways. The question now is: can the metabolic rift be mended? Or, at the very least, can human "waste" be widely incorporated into productive systems once again? 


\section{Opportunities and Obstacles for Bridging the Metabolic Rift}

Because food travels incredible distances in much of today's globalized economic system, directly "closing the loop" in nutrient cycling-or essentially returning all soil nutrients to their sites of origin-is an impractical and even impossible task. However, one area to improve global nutrient management can be in harnessing human excrement and redirecting it into degraded lands. Contemporary research has shown that in areas where soils have been depleted, the application of night soil or biosolids-treated sanitation wastes - can improve soil structure and soil porosity while also increasing soil organic carbon (García-Orenes et al. 2005; Tian et al. 2009). In New Mexico, for example, a study by Aguilar and Loftin (1991) demonstrated that biosolids were far more effective at restoring degraded rangelands suffering from soil erosion and nutrient depletion due to overgrazing than rangeland management through natural regeneration (i.e., by simply removing cattle). Biosolids have also proven to be effective in land reclamation, particularly for re-establishing vegetation and ecosystem services on lands degraded by extensive mining activity (Sopper 1992).

Beyond this, the improved management of human excreta can diminish dependency on commercial fertilizers. This is especially important because mined phosphorus is a finite natural resource that is expected to become depleted in the next 50 to 100 years (Cordell et al. 2011). Agronomic research has also shown that biosolids produce effects similar to commercial fertilizers on crop yields and plant nutrition, but have the added benefit of providing essential micronutrients (Basta 1995).

Like any soil amendment, the benefits of night soil or biosolids are partially contingent on the physical, chemical, and biological properties of the application site and many challenges remain in their management. This holds both for communities where human excreta is largely collected without treatment-particularly in the developing world-as well as contexts in which treated sanitation sludge is used. Below, we briefly present case studies from Ghana and the US to highlight some of the principal problems involving the management of these resources: pathogens, environmental pollution, transportation and logistics, and cultural taboo.

\section{Night Soil Management in Ghana}

In Ghana, night soil is commonly used in rural areas (including an estimated $64 \%$ of farmers in the Tamale and Bolgatanga regions) to increase yields of crops like maize and sorghum, helping to overcome limitations posed by poor soils and cost restrictions that hinder access to commercial fertilizers (Cofie et al. 2005). To reduce the risks associated with pathogen transmission, night soil is only generally applied to cereal crops that will be cooked or used for animal fodder. Although pit composting is sometimes practiced, night soil otherwise receives little treatment. Common logistical challenges include long transportation distances from nearby cities and frequent shortages. The cultural acceptance of such fertilizers also governs their use. As recent research in Ghana has shown (Buit and Jansen 2016), the physical appearance of the resource-how it is seen and smelled-has a significant impact on its adoption by farmers, especially as social scientists have characterized Ghanaian society as being "fecophobic" (Van der Geest 1998).

To improve upon current management, composting can be helpful for pathogen-reduction, but having a consistent and reliable source of carbon (e.g., straw, hay, sawdust) is needed to sustain output. The prevention of soil-transmitted parasites also requires safe excreta handling strategies, including personal protective equipment (e.g., gloves and boots) and regular antiparasitic prophylaxis (Tran-Thi et al. 2017). These practices also raise critical questions about human labor. Management of human excreta is a stigmatized occupation in Ghana and many other nations, often performed by marginalized classes or minority ethnic groups (e.g., Van der Geest 2002). Beyond making fertilizer that is safe and acceptable to users, the future of night soil management in Ghana and other countries requires considerations of social justice as well.

\section{Biosolids Use in the US}

In countries that rely on treated sanitation sludge, concerns have been raised about potential issues of toxicity and heavy metal bioaccumulation resulting from biosolids use in human food production as well as risks of disease and parasite transmission (Basta 1995; LeBlanc et al. 2006; Turton 1995). Untreated sanitation sludge can contain high concentrations of heavy metals (e.g., lead, copper, and cadmium), 
hazardous residual chemicals (e.g., PCBs and antibiotics), as well as parasitic helminth eggs (Basta 1995; LeBlanc et al. 2006). These problems, along with more generalized negative perceptions of biosolids used in food production, have limited their adoption in many developed regions of the globe (LeBlanc et al. 2006).

In the US, biosolids production and application are regulated by the Environmental Protection Agency (EPA) under the Part 503 rule of the Clean Water Act. Results from the EPA's national sewage sludge surveys have shown that regulated compounds (arsenic, cadmium, copper, lead, mercury, molybdenum, nickel, selenium, and zinc) in sewage sludge at wastewater treatment facilities consistently fall below ceiling levels ( $\mathrm{Lu}$ 2012). However, one challenge in the application of biosolids is that excessive use can result in unabsorbed nitrogen and phosphorus leaching into groundwater and surface water, resulting in the eutrophication of downstream waterbodies. Research in the US has specifically shown that application of biosolids based on plant nitrogen requirements alone can lead to the build-up of soil phosphorus in excess of crop requirements, which can then contribute to nonpoint source phosphorus pollution of surface waters (Penn and Sims 2002). However, such impacts also depend upon individual wastewater treatment plant processes, since some plants produce biosolids using lime and/or metal salts, while others do not. Furthermore, the organic matter content of biosolids can help to lockup environmental pollutants over time, which makes them less bioavailable to plants and thus reduces the risk of bioaccumulation or leaching into local water supplies (Basta 1995; Sopper 1992).

In 2002, the US National Research Council reported that there was no documented scientific evidence that the application of biosolids had adverse effects on public health. Today, however, micropollution in sewage, such as personal-care products, pharmaceuticals, and endocrine-disrupting compounds have raised new concerns among the public. The influence of these micro-pollutants on soil quality and human health requires further investigation, especially considering that the EPA (2018) has recently acknowledged that it lacks the necessary data to determine the safety of many industrial pollutants. Although a growing number of cities in the US are currently looking to expand the beneficial use of sanitation sludge-for forestry

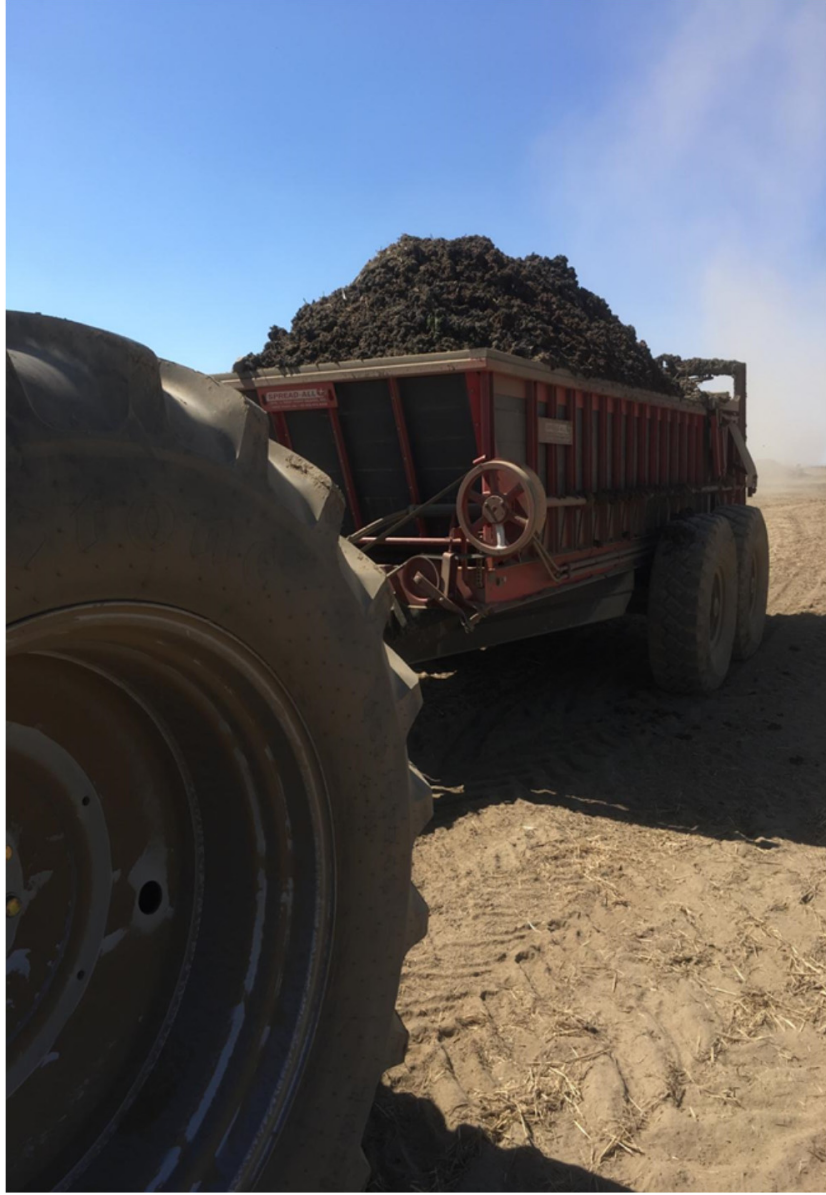

Figure 3 Class B biosolids are used to fertilize 90,000 acres of dryland wheat fields managed by over 100 landowners in the Boulder Park area of Washington state, USA. (Photograph by Nicholas C. Kawa).

projects and industrial agriculture as well as urban gardening-questions about the long-term effects of biosolids still remain.

\section{Conclusion}

As Marx argued nearly 150 years ago, industrial capitalism turned human excrement from an agricultural resource into a source of waste. The "culture of flushing" that developed during European industrialization perpetuates this negative attitude toward human excrement and sewage in societies throughout the world today (e.g., Morales et al. 2014). However, a growing movement of farmers, sanitation engineers, and scholars see the use of human excreta as one alternative method for agricultural fertilization on a planet of dwindling resources (Figure 3). Nonetheless, "closing the loop" in nutrient cycling requires negotiating a series of challenges. First, it 
demands better management of pathogens, particularly in the developing world, to minimize the threats to public health. Second, it requires greater attention to issues of environmental pollution, including the problems of excessive fertilization and the long-term effects of pharmaceuticals and industrial pollutants that persist in sanitation sludge. Third, the use of night soil and biosolids can only expand with logistical and infrastructural support, which continues to be sorely lacking in many parts of the world. Fourth, the stigmatization of such resources and the laborers responsible for their management will pose an ongoing obstacle to building a food system that integrates human excreta in a sustainable manner. Taking all of these factors into consideration, it cannot be denied that the bodily substances we all produce are critical elements of our ecosystems, and how we manage them will continue to have significant consequences for the global environment. With increasing recognition of an ecological crisis facing humanity, we simply cannot afford to hide from our "waste" anymore.

\section{Declarations}

Permissions: None declared.

Sources of funding: None declared.

Conflicts of Interest: None declared.

\section{References Cited}

Aguilar, R., and S. R. Loftin. 1991. Sewage Sludge Application in Semiarid Grasslands: Effects on Runoff and Surface Water Quality. Proceedings of the 36th Annual New Mexico Water Conference: Agencies and Science Working for the Future. Report (No. 265). New Mexico Water Resources Research Institute, Las Cruces.

Arroyo-Kalin, M. 2010. The Amazonian Formative: Crop Domestication and Anthropogenic Soils. Diversity 2:473-504. DOI:10.3390/d2040473.

Basta, N. 1995. Sewage Sludge Composition and Transformations. In Land Application of Biosolids: A Review of Research Concerning Benefits, Environmental Impacts, and Regulations of Applying Treated Sewage Sludge, edited by N. T. Basta, pp. 5-12. Oklahoma State University Press, Stillwater, OK.

Benidickson, J. 2007. The Culture of Flushing: A Social and Legal History of Sewage. UBC Press, Vancouver.

Birk, J. J., W. G. Teixeira, E. G. Neves, and B. Glaser. 2011. Faeces Deposition on Amazonian Anthrosols as Assessed from 5 $\beta$-Stanols. Journal of Archaeological Science 38:1209-220. DOI:10.1016/j.jas.2010.12.015.

Buit, G., and K. Jansen. 2016. Acceptance of Human Feces-Based Fertilizers in Fecophobic Ghana. Human Organization 75:97-107. DOI:10.17730/0018-7259-75.1.97

Chalfin, B. 2014. Public Things, Excremental Politics, and the Infrastructure of Bare Life in Ghana's City of Tema. American Ethnologist 41:92-109.

DOI:10.1111/amet.12062

Cofie, O. O., G. Kranjac-Berisavljevic, and P. Drechsel. 2005. The Use of Human Waste for PerUrban Agriculture in Northern Ghana. Renewable Agriculture and Food Systems 20:73-80. DOI:10.1079/ RAF200491.

Cordell, D., A. Rosemarin, J. J. Schroder, and A. L. Smit. 2011. Towards a Global Phosphorus Security: A System Framework for Phosphorus Recovery and Reuse Options. Chemosphere 84:747-758.

DOI:10.1016/j.chemospher.2011.02.032.

EPA. 2018. EPA Unable to Assess the Impact of Hundreds of Unregulated Pollutants in LandApplied Biosolids on Human Health and the Environment. US Environmental Protection Agency. Report number 19-P-0002. Available at: https://www.epa.gov/sites/production/files/201811/documents/_epaoig_20181115-19-p-0002.pdf. Accessed on June 23, 2019.

Elias, N. 2000. The Civilising Process: Sociogenetic and Psychogenetic Investigations. Wiley-Blackwell, London.

Feenstra, G. 2002. Creating Space for Sustainable Food Systems: Lessons from the Field. Agriculture and Human Values 19:99-106. DOI:10.1023/ A:1016095421310.

Ferguson, D. T. 2014. Nightsoil and the "Great Divergence": Human Waste, the Urban Economy, and Economic Productivity, 1500-1900. Journal of Global History 9:379-402. DOI:10.1017/ s1740022814000175.

Foster, J. B. 1999. Marx's Theory of Metabolic Rift: Classical Foundations for Environmental Sociology. American Journal of Sociology 105:366-405.

DOI:10.1086/210315.

Gandy, M. 2004. Rethinking Urban Metabolism: Water, Space, and the Modern City. City 8:363-379. DOI:10/1080/1360481042000313509.

García-Orenes, F., C. Guerrero, J. Mataix-Solera, J. Navarro-Pedreño, I. Gómez, and J. Mataix-Beneyto. 
2005. Factors Controlling the Aggregate Stability and Bulk Density in Two Different Degraded Soils Amended with Biosolids. Soil and Tillage Research 82:65-76. DOI:10.1016/j.still.2004.06.004.

Glaser, B., and J. J. Birk. 2012. State of the Scientific Knowledge on Properties and Genesis of Anthropogenic Dark Earths in Central Amazonia (Terra Preta de Índio). Geochimica et Cosmochimica Acta 82:39-51. DOI:10.1016/j.gca.2010.11.029.

Hanley, S. B. 1987. Urban Sanitation in Preindustrial Japan. The Journal of Interdisciplinary History 18:1-26. DOI:10.2307/204726.

Hawkins, G. 2003. Down the Drain: Shit and the Politics of Disturbance. In Culture and Waste: The Creation and Destruction of $V$ alue, edited by $G$.

Hawkins and S. Muecke, pp. 39-52. Rowman and Littlefield, Lanham, MD.

Jenkins, J. C. 1994. The Humanure Handbook: A Guide to Composting Human Manure (Emphasizing Minimum Technology and Maximum Hygenic Safety). 3rd edition. Jenkins Publishing, Grove City, PA.

Jia, S., and P. Huang. 1977. Qi Min Yao Shu. Agricultural Publishing House of China, Beijing.

Johnson, S. 2006. The Ghost Map: The Story of London's Most Terrifying Epidemic - And How It Changed Science, Cities, and the Modern World. Riverhead Books, New York, NY.

Kawa, N. C. 2016a. What Happens When We Flush? Anthropology Today 8:34-43. DOI:10.1080/194282000.2016.1202580.

Kawa, N. C. 2016b. Amaronia in the Anthropocene: People, Soils, Plants, Forests. University of Texas Press, Austin, TX.

Kim, M. J., H. C. Ki, S. Kim, J. Y. Chai, M. Seo, C. S. Oh, and D. H. Shin. 2014. Parasitic Infection Patterns Correlated with Urban-Rural Recycling of Night Soil in Korea and Other East Asian Countries: The Archaeological and Historical Evidence. Korean Studies 38:51-74.

King, F. H. 1911. Farmers of Forty Centuries, or Permanent Agriculture in China, Korea and Japan. Mrs. Franklin Hiram King, Madison, WI.

Langdon, K.A., M. S. J. Warne, and R. S. Kookana. 2010. Aquatic Hazard Assessment for Pharmaceuticals, Personal Care Products, and Endocrine-Disrupting Compounds from BiosolidsAmended Land. Integrated Environmental Assessment and Management 6:663-676. DOI:10.1002/ieam.74.
LaPorte, D. 2002. History of Shit. MIT Press, Cambridge, MA.

LeBlanc, R.J ., P. Matthews, and R. P. Richard. 2006. Global Atlas of Excreta, W astewater, Sludge and Biosolids Management, Moving Forward the Sustainable and Welcome Uses of a Global Resource. Greater Moncton Sewerage Commission Report.

Lu Q., Z. L. He, and P. J. Stoffella. 2012. Land Application of Biosolids in the US-A Review. Applied and Environmental Soil Science. Article ID 01462. DOI:10.1155/2012/201462

Marx, K. 1979. Capital, Volume 1. International Publishers, New York, NY.

Marx, K. 1999. Capital, Volume 3. International Publishers, New York, NY.

McNeill, J. R., and V. Winiwarter. 2004. Breaking the Sod: Humankind, History, and Soil. Science 304:1627-629. DOI:10.1126/science.1099893.

Merlín-Uribe, Y., C. E. González-Esquivel, A. Contreras- Hernández, L. Zambrano, P. MorenoCasasola, and M. Astier. 2013. Environmental and Socio-Economic Sustainability of Chinampas (Raised Beds) in Xochimilco, Mexico City. International Journal of Agricultural Sustainability 11:216-233, DOI:10.1080/14735903.2012.726128.

Moore, J. W. 2011. Transcending the Metabolic Rift: A Theory of Crises in the Capitalist World-Ecology. The Journal of Peasant Studies 38:1-46.

DOI:10.1080/03066150.2010.538579.

Moraes, C. D. P. 2015. O Determinismo Agrícola na Arqueologia Amazônica. Estudos Avançados 29:25-43. DOI:10.1590/S010340142015000100004.

Morales, M. D. C., L. Harris, and G. Öberg. 2014. Citizenshit: The Right to Flush and the Urban Sanitation Imaginary. Environment and Planning $A$ 46:2816-2833. DOI:10.1068/a130331p.

Neves, E. G., J. B. Petersen, R. N. Bartone, and C. A. Da Silva. 2003. Historical and Socio-cultural Origins of Amazonian Dark Earth. In Amazonian Dark Earths, edited by J. Lehmann, D. C. Kern, B. Glaser, and W. I. Woods, pp. 29-50. Springer, Dordrecht, Netherlands.

Penn, C. J., and J. T. Sims. 2002. Phosphorus Forms in Biosolids-Amended Soils and Losses in Runoff. Journal of Environmental Quality 31:1349-1361. DOI:10.2134/jeq2002.1349. 
Pickering, L. 1999. Toilets, Bodies, Selves: Enacting Composting as Counterculture in Hawai'i. Body \& Society 16:33-55. DOI:10.1177/1357034X10383882.

Robins, S. 2014. Poo Wars as Matter Out of Place: "Toilets for Africa" in Cape Town. Anthropology Today 30:1-3. DOI:10.1111/1467-8322.12081.

Smil, V. 2004. Enriching the Earth: Fritz. Haber, Carl Bosch, and the Transformation of World Food Production. MIT Press, Cambridge, MA.

Snyder, C. 2005. The Dirty Work of Promoting "Recycling" of America's Sewage Sludge. International Journal of Occupational and Environmental Health 11:415-427. DOI:10.1179/ oeh.2005.11.4.415.

Sopper, W. E. 1992. Reclamation of Mine Land Using Municipal Sludge. In Soil Restoration, edited by R. Lal and B. A. Stewart, pp. 351-431. Springer, New York, NY.

Tian, G., T. C. Granato, A. E. Cox, R. I. Pietz, C. R. Carlson, and Z. Abedin. 2009. Soil Carbon Sequestration Resulting from Long-Term Application of Biosolids for Land Reclamation. Journal of Environmental Quality 38:61-74. DOI:10.2134/jeq2007.0471.

Tran-Thi, N., R. J. Lowe, J. M. Schurer, T. Vu-Van, L. E. MacDonald, and P. Pham-Duc. 2017. Turning
Poop into Profit: Cost-Effectiveness and Soil Transmitted Helminth Infection Risk Associated with Human Excreta Reuse in Vietnam. PLoS Neglected Tropical Diseases 11:e0006088. DOI:10.1371/journal.pntd.0006088.

Turton, D. J. 1995. Potentials and Problems of Municipal Sludge Utilization on Oklahoma Forestlands. In Land Application of Biosolids: A Review of Research Concerning Benefits, Environmental Impacts, and Regulations of Applying Treated Sewage Sludge, edited by N. T. Basta, pp. 19-30. Oklahoma State University Press, Stillwater, OK.

Van Der Geest, S. 1998. Akan Shit: Getting Rid of Dirt in Ghana. Anthropology Today 14:8-12. DOI:10.2307/2783049.

Van Der Geest, S. 2002. The Night-Soil Collector: Bucket Latrines in Ghana. Postcolonial Studies: Culture, Politics, Economy 5:197-206. DOI:10.1080/1368879022000021092.

Wheeler, C. 1887. Sewers: Ancient and Modern. Nabu Press, Charleston, SC.

Xue, Y. 2005. "Treasure Nightsoil as if It Were Gold:" Economic and Ecological Links between Urban and Rural Areas in Late Imperial Jiangnan. Late Imperial China 26:41-71. DOI:10.1353/ late.2005.0009. 